\title{
Short Communication: Assessment of reclamation success of former limestone quarries in Tuban, Indonesia, based on soil arthropod diversity and soil organic carbon content
}

\author{
DWI OKTAFITRIA ${ }^{1}$, KUNTUM FEBRIYANTININGRUM ${ }^{1}$, NURUL JADID ${ }^{2}$, NIA NURFITRIA ${ }^{1}$, \\ FAHMI RAHMADANI ${ }^{2}$, ALFIAN AMRULLAH ${ }^{2}$, DEWI HIDAYATI ${ }^{2, \bullet}$ \\ ${ }^{1}$ Department of Biology, Faculty of Mathematics and Natural Sciences. Universitas PGRI Ronggolawe. Jl. Manunggal No. 61, Gedongombo, Tuban \\ 62381, East Java, Indonesia \\ ${ }^{2}$ Department of Biology, Faculty of Science, Institut Teknologi Sepuluh Nopember.Jl. Raya ITS, Keputih, Sukolilo, Surabaya 60111, East Java, \\ Indonesia. `email: dewi_hidayati@ymail.com
}

Manuscript received: 7 February 2019. Revision accepted: 29 May 2019.

\begin{abstract}
Oktafitria D, Febriyantiningrum K, Jadid N, Nurfitria N, Rahmadani F, Amrullah A, Hidayati D. 2019. Assessment of reclamation success of former limestone quarries in Tuban, Indonesia, based on soil arthropod diversity and soil organic carbon content. Biodiversitas 20: 1743-1747. The reclamation for sustainable ecosystem in mined land, including revegetation, is an obligatory program stipulated by the Indonesian government. This study evaluated the ecological improvement of revegetated land at the reclamation sub-areas (RSAs) of former limestone quarries in Tuban, East Java, Indonesia. The RSAs were coded as RSA 2010, RSA 2014, and RSA 2016 which represented the initial year of revegetation as well as the reclamation soil-material, namely the rejected soilproducts, topsoil, and spoils, respectively. Soil insects were collected from ten sampling plots at each RSA using pitfall traps. The data of arthropods were analyzed to describe the community structure by determining the Shannon Diversity Index (H'), Simpson's index (D), Sorensen's similarity and Shannon evenness index (E). The soil organic carbon (SOC) content from the soil composites was analyzed according to the Walkley and Black method. The results showed that SOC value at RSA $2010(1.851 \pm 0.38 \%)$ was higher than that at SRA $2014(1.694 \pm 0.29 \%)$ and SRA $2016(0.947 \pm 0.10 \%)$. There were 18 families found from eight orders of soil insects (Coleoptera, Diplura, Diptera, Entognatha, Hemiptera, Hymenoptera, Neuroptera, and Orthoptera) and one order from terrestrial crustacea i.e., Isopoda, family Tylidae. The ecological indices of RSA $2014\left(\mathrm{H}^{\prime}=1.15 ; \mathrm{D}=0.47 ; \mathrm{E}=0.61\right)$ and RSA $2016\left(\mathrm{H}^{\prime}=1,19\right.$; $\mathrm{D}=0.47 ; \mathrm{E}=0.57)$ were higher than those of RSA $2010\left(\mathrm{H}^{\prime}=0,61 ; \mathrm{D}=0.71 ; \mathrm{E}=0.43\right)$. The Pearson analysis indicated moderate negative correlation $(\mathrm{r}=0.55)$ between soil arthropod diversity index and SOC. The diversity of soil arthropods at reclaimed area indicated that the reclamation was successful. Based on the study, we recommend that reclamation is done using mine spoil or topsoil rather than rejected soil products.
\end{abstract}

Keywords: Carbon, diversity, reclamation, soil arthropods

\section{INTRODUCTION}

Tuban is an Indonesian district which has high potential of karst; hence, limestone mining has been done to serve the Indonesian cement industries. The open mining of limestone degrades the land surfaces including the loss of vegetation, changes in the soil structure and density, and causes erosion, and water pollution (Rai et al. 2014; Suthirat 2017). The land reclamation and revegetation in several former limestone quarries in Tuban district have been conducted. There are three types of reclamation subareas (RSAs), namely RSA 2010, RSA 2014, and RSA 2016, the names referring to the initial year of reclamation and revegetation as well as the reclamation soil materials. The RSA 2010 mainly consisted of rejected soil-products (the rest of mining soil after limestone extraction for cement production), while the RSA 2014 and RSA 2016 consisted of topsoil and mine spoil, respectively. The current evaluation of reclaimed and revegetated lands in Tuban's post-mining areas is still focusing on the growth of vegetation. Meanwhile, there is little information regarding the soil fauna and abiotic factors which have important role in sustainable land reclamation. Land preparation is the first step in reclamation which involves succession, namely changes of ecological community over time due to the changes of biotic and abiotic factors. Succession is generally influenced by local plants and animals, including arthropods that represent about $85 \%$ of the soil fauna (Culliney 2013). The soil arthropods such as beetles, spiders, grasshoppers, and ants can explain the status of land reclamation because of their sensitivity to environmental changes (Buchori et al. 2018). The soil insects have an important role in the process of decomposing organic matter in the soil which increases the soil productivity. Furthermore, the activities of soil insects in the soil improve aeration, water infiltration, and soil aggregation. The abundance and diversity of soil insects are strongly influenced by the macro and microelements in the soil (Liu et al. 2006; Njira and Nabwami 2013). This study was aimed to evaluate the reclamation and 
revegetation of limestone quarries in Tuban based on diversity of soil arthropods and soil organic carbon (SOC).

\section{MATERIALS AND METHODS}

This research was conducted in the reclamation areas of a former limestone mine in Tuban district, East Java Province, Indonesia (Figure 1a) which have been reclaimed and revegetated with Tectona grandis and Leucaena leucocephala. Soil and soil arthropods were collected from three sampling sites, namely RSA 2010, RSA 2014 and RSA 2016 which have been previously described. There were ten plots at each RSA (Figure 1b)

The sampling of soil arthropods was carried out using the pitfall trap method modified by Majer et al. (2007). One hundred-meter transects were made in the representative areas in SRA 2010, SRA 2014 and SRA 2016. Plastic cups, $10 \mathrm{~cm}$ in diameter and 13 in height (size $24 \mathrm{oz}$ ), were inserted into the soil until the mouths of the plastic cups were parallel to the soil surface. The distance from one cup to another was 10 meters. One-third of plastic cups were filled with soapy water and left open for six days, allowing time for soil arthropods to be trapped into plastic cups. The trapped arthropods were collected and placed in bottles of
$70 \%$ alcohol, then identified to the family level at laboratory using the reference key of Borror et al. (1996).

Referring to Patil method (2002), 200 grams of composite soil samples were collected from 10 sampling plots. The soil organic carbon (SOC) test was done using the Walkley and Black method based on the amount of organic material that is easily oxidized. The principle of this method is to use easily oxidized organic matter in the soil to reduce excess $\mathrm{Cr}_{2} \mathrm{O}_{7}{ }^{2+}$. The soil samples were added with $\mathrm{H}_{2} \mathrm{SO}_{4}$ and $\mathrm{K}_{2} \mathrm{Cr}_{2} \mathrm{O}_{7}$, then the remaining $\mathrm{Cr}_{2} \mathrm{O}_{7}{ }^{2+}$ was measured by titration using FeSO4. Furthermore, it was calculated using a formula (Angelova 2014):

$\% C-$ Organic $=\frac{\left\lfloor\left(N_{\mathrm{K} 2 \mathrm{Cr} 2 \mathrm{O} 7} \times V_{\mathrm{K} 2 \mathrm{Cr} 207}\right)-\left(N_{\mathrm{FeSO}} \times V_{\mathrm{FeS} 04}\right)\right\rfloor \times 0.03 \times 1.30}{\text { Absolute Dry Weight in } 105^{\circ} \mathrm{C}} \times 100 \%$

Soil arthropod community's attributes were described using indices, to the family level, namely Shannon diversity index $\left(\mathrm{H}^{\prime}\right)$, Simpson dominance index (D), Sørensen community similarity index (IS) and evenness index (E) (Magurran 2004). Statistically, the correlation between soil arthropod diversity and SOC was determined using Pearson correlation analysis.

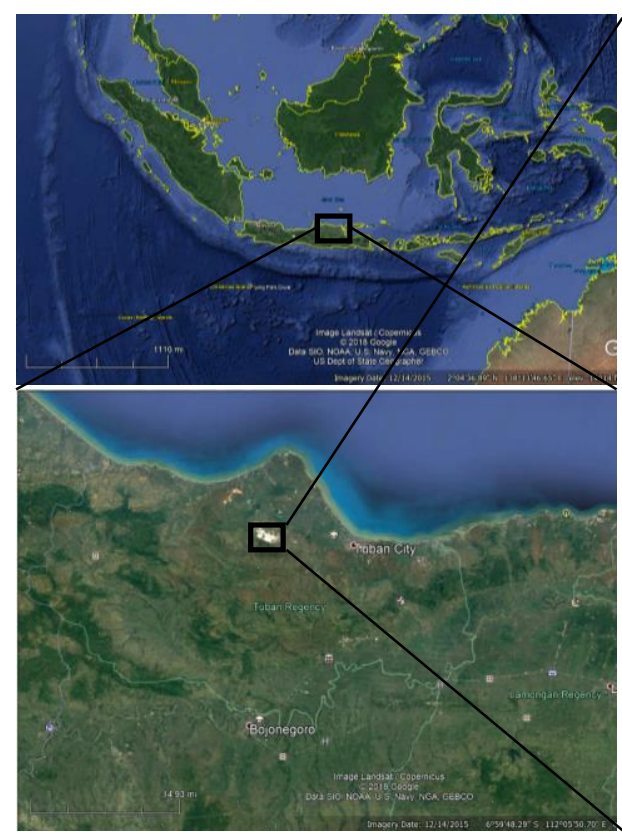

A
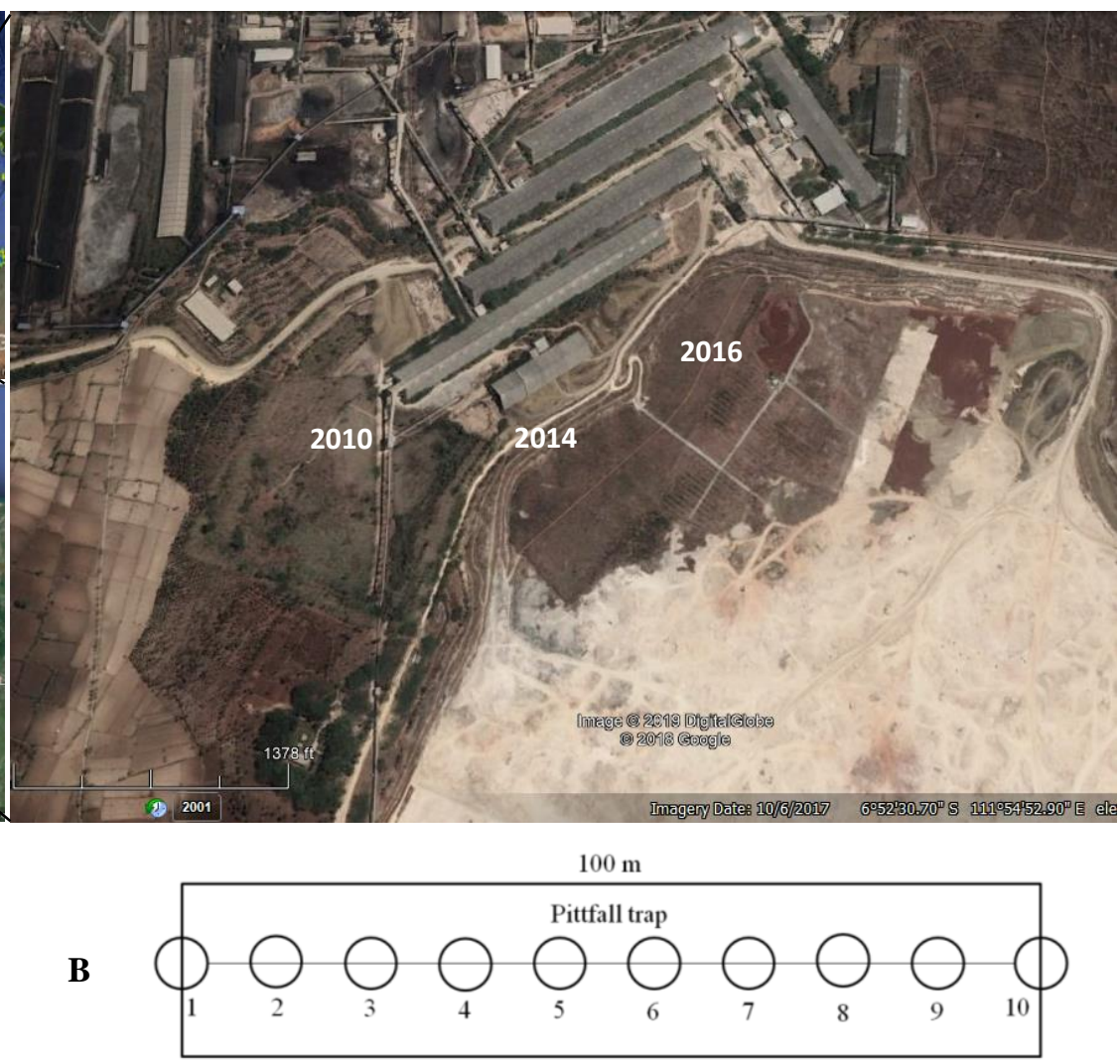

Figure 1. A. Sampling sites in reclamation and revegetation areas of limestone post-mining in Tuban district, East Java, Indonesia that consist of three Reclamation Sub-Areas, i.e.: RSA 2010, RSA 2014, RSA 2016; B. Pitfall traps placed along $100 \mathrm{~m}$ transect at each RSA 


\section{RESULTS AND DISCUSSION}

\section{Soil organic carbon}

The SOC is reduced at drylands due to evaporation and it increases with the increasing soil water moisture (Huang et al. 2015). However, Mureva et al. (2018) found that value of SOC in semi-arid regions was higher than that in humid regions due to the presence of woody plants. The result in current study was likely similar with Mureva's founding since the sampling site of RSA 2010 which was reclaimed with drier soil, i.e., the rejected products of soil, had higher SOC value $(1.851 \pm 0.38 \%)$ than SRA 2014 $(1.694 \pm 0.29 \%)$ and SRA $2016(0.947 \pm 0.10 \%)$. This phenomenon is also possibly related to the age of reclamation: higher SOC was found in the older reclamation area. The high SOC in the RSA 2010 could be due to the large piles of organic materials from litter every year, mainly in rainy season (Regina and I Santa 2001; Averti et al. 2018). Generally, based on the quality standards of soil quality stipulated by the Ministry of Agriculture's Soil Research Center (1983), SOC in the three sampling sites of RSA was categorized as very low to low $(<1.0-2.0 \%)$.

\section{Soil arthropods}

In overall sampling sites 18 families were found from eight soil orders of insects (Coleoptera, Diplura, Diptera, Entognatha, Hemiptera, Hymenoptera, Neuroptera and Orthoptera) and one terrestrial crustacea family, i.e., Tylidae, of the order Isopoda (Table 1). Three families were observed at all sampling sites i.e: Formicidae $( \pm$ $69.5 \%)$, Isopoda $( \pm 10 \%)$ and Entognatha $( \pm 2.4 \%)$. The abundance of Formicidae at all RSAs indicated that the environmental conditions of RSAs met the optimal abiotic factors for that soil arthropods. The observed temperatures ranged from $28^{\circ} \mathrm{C}$ to $30^{\circ} \mathrm{C}$ and $\mathrm{pH}$ ranged from 5.5 to 7 , optimum to support the activity of Formicidae (Yuniar and Haneda 2015) The optimum temperature for Formicidae in tropical climate is $25-32^{\circ} \mathrm{C}$ (Buchori's 2018). Ants (Formicidae) are the most dominant arthropod since they succeed in exploiting food resources efficiently and they do cooperative foraging (Traniello 1989).

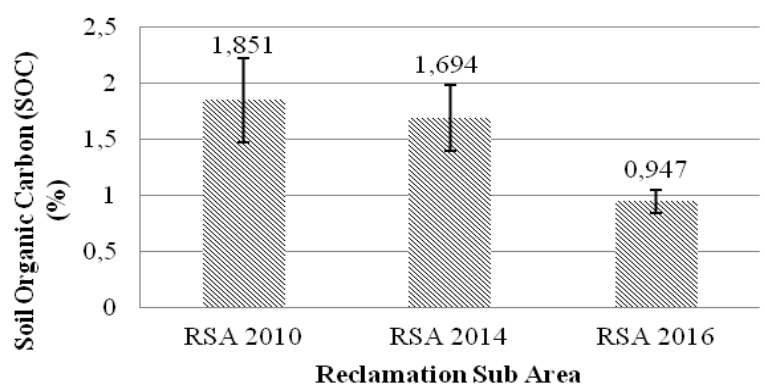

Figure 2. Soil organic carbon (SOC) in the RSA 2010, RSA 2014 and RSA 2016

Table 1. Individual number of soil arthropods at reclaimed and revegetated sub areas in former limestone quarries in Tuban district, East Java, Indonesia

\begin{tabular}{|c|c|c|c|c|c|c|c|c|c|c|}
\hline \multicolumn{2}{|c|}{ Soil arthropods } & \multicolumn{9}{|c|}{ Individual number of soil arthropod at RSA (triplicates sampling) } \\
\hline \multirow{2}{*}{ Order } & \multirow{2}{*}{ Family } & \multicolumn{3}{|c|}{ RSA 2010} & \multicolumn{3}{|c|}{ RSA 2014} & \multicolumn{3}{|c|}{ RSA 2016} \\
\hline & & $\mathbf{n}_{1}$ & $\mathbf{n}_{2}$ & $\mathbf{n}_{3}$ & n1 & n2 & n3 & n1 & n2 & n3 \\
\hline \multirow[t]{5}{*}{ Coleoptera } & Coccinelidae & 300 & 109 & 288 & 0 & 0 & 0 & 18 & 29 & 44 \\
\hline & Silphidae & 222 & 144 & 214 & 48 & 33 & 11 & 36 & 48 & 75 \\
\hline & Scarabaeidae & 24 & 14 & 22 & 402 & 85 & 40 & 12 & 14 & 10 \\
\hline & Staphylinidae & 114 & 78 & 112 & 96 & 17 & 14 & 126 & 170 & 129 \\
\hline & Carabidae & 0 & 0 & 0 & 282 & 58 & 22 & 0 & 0 & 0 \\
\hline Diplura & Campodeidae & 0 & 0 & 0 & 0 & 0 & 0 & 96 & 165 & 99 \\
\hline \multirow[t]{2}{*}{ Diptera } & Sciaridae & 72 & 28 & 66 & 0 & 0 & 0 & 0 & 0 & 0 \\
\hline & Simuliidae & 150 & 108 & 142 & 12 & 0 & 10 & 102 & 169 & 98 \\
\hline Entognatha & Entomobryidae & 96 & 56 & 92 & 264 & 91 & 172 & 228 & 220 & 275 \\
\hline \multirow{4}{*}{ Hemiptera } & Nabidae & 138 & 116 & 126 & 54 & 10 & 35 & 0 & 0 & 0 \\
\hline & Fulgoroidea & 48 & 26 & 46 & 24 & 15 & 22 & 222 & 293 & 251 \\
\hline & Cicadellidae & 180 & 194 & 178 & 0 & 0 & 0 & 48 & 93 & 87 \\
\hline & Cercopidae & 0 & 0 & 0 & 150 & 53 & 43 & 264 & 171 & 258 \\
\hline \multirow{3}{*}{ Hymenoptera } & Formicidae & 5364 & 6950 & 6460 & 2154 & 2736 & 2169 & 4836 & 6885 & 4027 \\
\hline & Evaniidae & 42 & 42 & 38 & 222 & 101 & 123 & 90 & 99 & 96 \\
\hline & Myrmicidae & 24 & 26 & 22 & 72 & 3 & 10 & 288 & 467 & 289 \\
\hline Isopoda & Tylidae & 90 & 53 & 88 & 1554 & 402 & 417 & 1212 & 1045 & 1226 \\
\hline Neuroptera & Myrmeleontidae & 0 & 0 & 0 & 102 & 45 & 59 & 0 & 0 & 0 \\
\hline Orthoptera & Gryllidae & 40 & 14 & 21 & 90 & 14 & 36 & 75 & 98 & 76 \\
\hline
\end{tabular}

Notes: RSA: Reclamation Sub Area; n: replication 


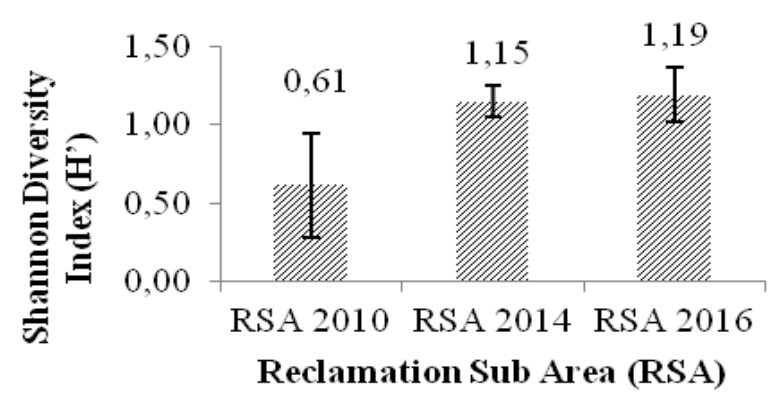

A

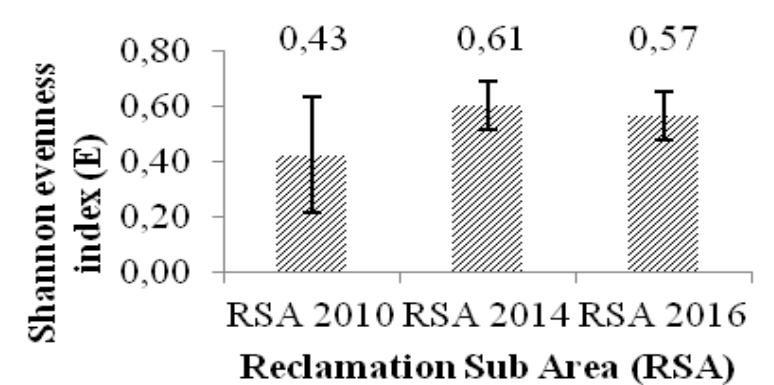

C

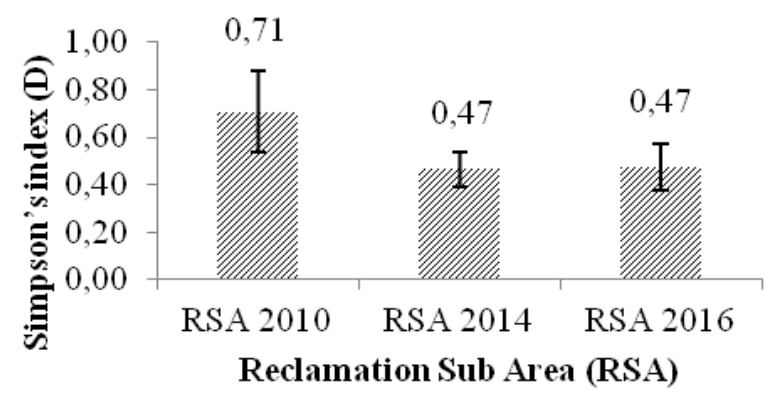

B

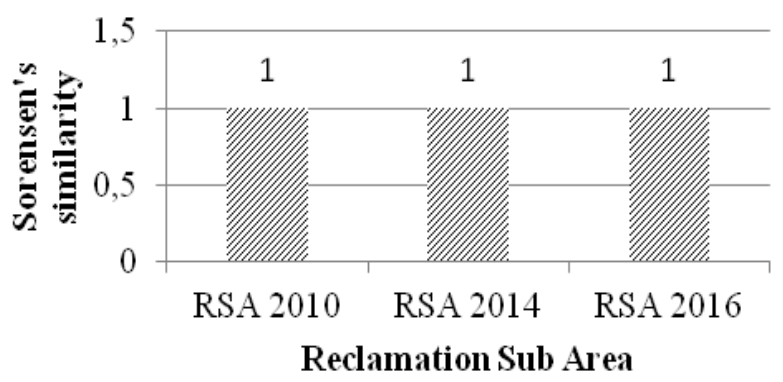

D

Figure 3. The ecological indices of soil arthropods: A. Shannon diversity Index (H'), B. Simpson index (D); C. Shannon evenness index (E'), D. Sørensen similarity of community

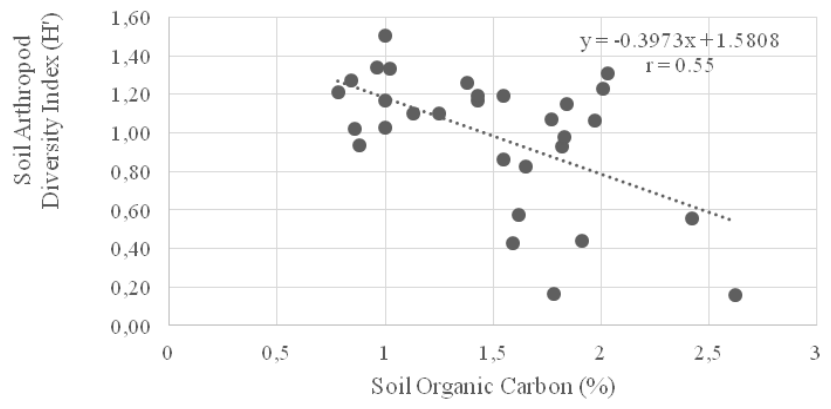

Figure 6. The Pearson Correlation between Soil Organic Carbon (SOC) and Soil Arthropod Diversity Index (H')

As previously describes, the higher SOC in SRA 2010 reclaimed using rejected soil indicates that soil in this location is semi-arid. The semi-arid condition at SRA 2010 may slow the decay process of litter from the surrounding vegetation. Moreover, the semi-arid soil may limit the soil fauna that needs moist condition such as Terrestrial Crustacea, Isopod, Tylidae. The example of Tylidae, Titanethes albus is found in moist limestone due to its weak exoskeleton (Vittori et al. 2012). Table 1 shows that Tylidae population at SRA 2010 was significantly lower than that in SRA 2014 and SRA 2016. All sampling sites of RSA had similar species composition, so the similarity index was 1 for every pair of sites compared (Figure 3d).
Meanwhile, the ants (Formicidae) are known as insect that are still abundant in arid ecosystems (MacKay 1991), hence their dominance will lower the family diversity index (Amarullah et al. 2017; Floder and Hillebrand 2012). Therefore, according to Figures 3.A-C, SRA 2010 had the lowest diversity index $\left(\mathrm{H}^{\prime}=0.61\right)$ as well as lowest of evenness index $(E=0.43)$, but the highest dominance index (0.71) due to the abundance of Formicidae (Table 1). This result was different from Buchori's (2018) statement that the diversity of soil insects tends to increase with increasing age of reclamation. In our current study, the difference in diversity may be affected more by the quality of reclamation soil media rather than the age of reclamation. The Pearson correlation analysis showed moderately negative correlation $(r=0.55)$ between soil arthropod diversity index and SOC.

The diversity of soil arthropods in all sampling RSA reflected the succession followed by ecological quality improvement in Tuban former limestone quarries. The SOC value was negatively correlated with soil arthropod diversity index ( $\left.\mathrm{H}^{\prime}\right)$ and possibly affected by the age of reclamation and reclamation media; hence further investigation is proposed. Despite having lower SOC and shorter reclamation time period, the reclamation of former limestone quarries using mine spoil or topsoil showed higher value of soil arthropod diversity index. We concluded that mine spoil and topsoil are better than rejected soil products. Therefore, these materials are more recommended than rejected soil products. 


\section{REFERENCES}

Amarullah ET, Trizelia, Andi, Yaherwandi, Hamid H. 2017. Diversity of plant species in paddy ecosystem in West Sumatra, Indonesia. Biodiversitas 18 (3): 1218-1225.

Angelova, Violina R, Akova, Vanja I, Ivanov, Krasimir I, Licheva, Penka A. 2014. Comparative study of titimetric methods for determination of organic carbon in soils, compost and sludge. J Intl Sci Publ: Ecol Saf 8: 430-440.

Averti, Ifo S, Urielle, Malonga M, et al. 2018. Litterfall, standing litter and leaves decomposition within urban tropical forest of Zoological Park of Brazzaville, Republic of the Congo. Res J Bot 13 (1): 1-10.

Buchori D, Rizali A, Rahayu GA, Mansur I. 2018. Insect diversity in postmining areas: Investigating their potential role as bioindicator of reclamation success. Biodiversitas 19 (5): 1696-1702.

Borror D, Triplehorn CH, Johnson NF. 1996. An Introduction to the Study of Insects. 6th ed. Saunders College Publishing, Ohio, USA.

Culliney, Thomas W. 2013. Role of arthropods in maintaining soil fertility. Agriculture 3: 629-659.

Floder S, Hillebrand H. 2012. Species traits and species diversity affect community stability in a multiple stressor framework. Aquat Biol 17 197-209.

Huang J, Yu H, Guan X, Wang G, Guo R. 2015. Accelerated dryland expansion under climate change. Nat Clim Ch 6: 166-171.

Islam KR, Weil RR. 2000. Soil quality indicator properties-in midAtlantic soils as influenced by conservation management. J Soil Water Conserv 55 (1): 69-78.

MacKay WP. 1991. The Role of Ants and Termites in Desert Communities. In: Polis GA (ed..). The Ecology of Desert Communities. University Arizona Press, Tucson, AZ.

Magurran AE. 2004. Measuring Biological Diversity. Blackwell Science, Oxford.
Majer JD, Orabi G, Bisevac L. 2007. Ants (Hymenoptera: Formicidae) pass the bioindicator scorecard. Myrmecol News 10: 69-76.

Ministry of Agriculture's Soil Research Center. 1983. Criteria for Assessing the Nature of Soil Chemical Analysis Data. Land Research Center, Bogor, Indonesia. [Indonesian]

Mureva A, Ward D, Pillay T, Pauline C, Cramer M. 2018. Soil organic carbon increases in semi-arid regions while it decreases in humid regions due to woody-plant encroachment of grasslands in South Africa. Sci Rep (8): 15506: 1-12. DOI:10.1038/s41598-018-33701-7.

Njira KOW, Nabwami J. 2013. Soil management practices that improve soil health: Elucidating their implications on biological indicators. J Anim Plant Sci 18: 2750-2760.

Liu X, Herbert SJ, Hashemi AM, Zhang X, Ding G. 2006. Effect of agricultural management on soil organic matter and carbon transformation. Plant Soil Environ 52 (12): 531-543.

Patil GP. 2002. Encyclopedia of Environmetrics: Composite Sampling. Vol. 1. John Wiley \& Sons, Ltd., Chichester.

Rai VK, Raman NS, Choudhary SK, Rai, Srijana. 2014. Topsoil management in coal mines: A paradigm shift required in approach. $\mathbf{J}$ Innov Res Adv Eng 1 (10): 448-454.

Regina, I Santa. 2001. Litterfall, decomposition and nutrient release in three semi-arid forest of the Duero Basin, Spain. Forestry 74 (4): $347-$ 358.

Suthirat. 2017. Assessment of environmental impacts of limestone quarrying operations in Thailand. J Environ Clim Technol 20: 67-83.

Traniello, James FA. 1989. Foraging strategies of ants. Ann Rev Entomol 34: 191-210.

Vittori M, Kostanjšek R, Žnidaršič N, Štrus J. 2012. Molting and cuticle deposition in the subterranean trichoniscid Titanethes albus (Crustacea, Isopoda). ZooKeys 176: 23-38.

Yuniar N, Haneda NF. 2015. Ants diversity in four different ecosystem type in Jambi. Pros Sem Nas Masy Biodiv Indon 1 (7): 1582-1585. [Indonesian] 